\title{
Proteasome Subunit Beta Type-10
}

National Cancer Institute

\section{Source}

National Cancer Institute. Proteasome Subunit Beta Type-10. NCI Thesaurus. Code C112080.

Proteasome subunit beta type-10 (273 aa, $29 \mathrm{kDa})$ is encoded by the human PSMB10 gene. This protein is involved in the formation of peptide antigens by the immunoproteasome. 